Due to appear in Journal of Education \& Work October 2001

\title{
PART-TIME WORK AND
}

\section{FULL-TIME EDUCATION IN THE UK: \\ THE EMERGENCE OF A CURRICULUM \\ AND POLICY ISSUE}

Ann Hodgson \& Ken Spours

Institute of Education, University of London 


\section{PART-TIME WORK AND FULL-TIME EDUCATION IN THE UK: THE EMERGENCE OF A CURRICULUM AND POLICY ISSUE}

\section{ABSTRACT}

The 1990s have seen a burgeoning international, national and local literature on the significance of part-time work for those in full-time education. In this article, we trace the development of different strands of research in this area over the last decade. In common with other writers, we attribute the increased interest in the phenomenon of part-time work among full-time learners to changes in the youth labour market allied to rising levels of post-16 participation. Using evidence from three recent studies, we suggest that the scale and intensity of participation in part-time work amongst full-time 16-19 year olds appears to have increased significantly towards the end of the 1990s and that a growing commitment to part-time work is become the norm for learners in full-time 16-19 courses. Our research suggests, however, that learners in advanced level courses have related study and paid work in different ways and we develop a number of learner typologies to reflect this. In the final section we explore how the 'Qualifying for Success' qualification reforms (often referred to as 'Curriculum 2000'), which seek to expand study programmes for advanced level 16-19 year olds, might affect the relationship between earning and learning. We conclude by identifying a number of issues around earning and learning that we feel deserve further research and public debate. 


\section{RESEARCH ON EARNING AND LEARNING IN THE 1990s: FROM OBSERVATIONS OF CHANGE TO AN IMPORTANT POLICY ISSUE}

The changing nature of the youth labour market and post-16 participation over the last two decades provide the context for the growth of part-time work for 16-19 year olds involved in fulltime education in the UK. However, research during this period has tended to focus either on the lengthening of transitions between school and full-time work or the growth of full-time post-16 participation: research into the role of part-time work has remained relatively under-developed. During the early 1990s, however, this began to change and there was a steadily growing body of research in this area. Nevertheless, it was not until the late 1990s that the issue of part-time work among full-time learners in schools and colleges emerged as significant for education practitioners and began to appear in the national press.

The largest body of national and international literature on earning and learning has concentrated on child labour, youth exploitation, pay and conditions (e.g. work by Pond and Searle 1991, Hobbs and McKechnie 1997 and O'Donnell and White 1998). In the UK this followed more than a decade of deregulation of the economy and labour relations by successive Conservative governments. At the same time, research focusing on the consequences of the expansion of the service sector, increased labour market flexibility and the spread of casualisation also began to look at the issue of part-time youth labour with concerns about labour substitutionism (e.g. Dex and McCulloch 1995 and Hakim 1996).

By the mid-1990s, a number of studies began to focus more specifically on the role of part-time work among those in full-time education, suggesting that it was on the increase (e.g. Rikowski 1992, Micklewright et al. 1994, Dustmann et al. 1996, Lucas and Lammont 1998). These studies were accompanied by other perspectives which problematised the issue of youth transitions at a 
time of increasing full-time participation in post-16 education (e.g. Hodkinson et al. 1996, Bynner et al. 1997 and Ball et al. 2000).

As more young people in full-time education began to gain experience of the labour market, a strand of discussion developed on the skills and attributes gained from working life (e.g. Lucas and Lammont 1998, Raffe et al. 1998).

International studies of school to work transitions that acknowledged the growing role of parttime work also appeared alongside UK-based research (e.g. Dex and McCulloch 1995, Ford et al. 1995, Hannan et al. 1996, Rubery et al. 1998, Raffe et al. 1998). Two major findings emerged from this literature: that part-time work is on the increase across different European countries and types of economies (Rubery et al. 1998) and that it is affecting a younger age group as well as those in higher education (Ford et al. 1995). Rikowski (1992), in a local study on part-time work among full-time learners, raises the question as to whether this might be seen as a process of 'Americanisation'. He points out that in the US levels of participation in part-time work while in high school were already high in the 1980s. He also locates the main positive and negative effects of paid work on academic study and these, as we shall see below, show remarkable similarities to those now arising in the UK.

In the late-1990s, education professionals were becoming increasingly anxious about the number of students working part-time and more specifically, about those who appeared to be working long hours to the detriment of their studies. These concerns lay behind the burgeoning of local studies of part-time work amongst 16-19 year olds on advanced level courses (e.g. Coles 1998, Howard 1998, Davies 1998, Davies 1999, Richards and Oates 2000, Hodgson and Spours 2000a, 2000b). At the same time high-profile articles in the broadsheets and the specialist educational 
press started to raise public awareness that significant changes were taking place (Harrison 1998, Hodgson and Spours 1998, 2000c, Harris 1999)

So what had changed? The change appears to lie in the importance that part-time work has achieved in the lives of young people. Local studies, like those cited above, began to suggest that the vast majority of 16-19 year olds were working part-time on a regular basis, not just in school holidays but during the school week as well as at the weekend, with some undertaking substantial hours of work. These local studies also suggest that the incidence of part-time work amongst full-time 16-19 year olds is about 20 percentage points higher than indicated in data from the Labour Force Survey (DfEE 1999).

It appears that a number of factors have come together in the late 1990s to produce the kind of economic and social climate in which earning and learning, as in the US, has become the norm for 16-19 year olds in the UK. In our view, significant factors include the rapid spread of 24-hour opening in the retail trade; changes to the Sunday trading legislation; continued economic growth, particularly in the service sector; the appearance of new expensive objects of youth consumption (e.g. mobile phones) and the spectre of increased higher education debt.

Within this new context three new strands of research have emerged:

- the relationship between part-time work and the advanced level qualifications and curriculum system in this country (e.g. Hodgson and Spours 2000a, 2000b, 2000c);

- the impact of part-time work on A Level examination achievement (e.g. Howard 1998, ALIS 1999; Richard and Oates 2000) 
- the effects of part-time work on long-term aspirations and progression to higher education (Hodgson and Spours 1998, Hodgson and Spours 2000a).

These new studies raise the issue of whether the extent and intensity of part-time work among 1619 year olds is potentially on a collision course with key aspects of government policy, such as reforming advanced level qualifications, increasing educational attainment and increasing and widening participation in higher education.

We would argue that in the space of a decade the issue of part-time work for full-time 16-19 year olds in the UK appears to have moved from what was seen as a relatively minor factor in their transition from school to working life to an almost universal experience and an important policy issue.

\section{FINDINGS FROM THREE RECENT STUDIES ON EARNING AND LEARNING}

\section{The three studies}

In this section we draw on three recent studies (Hodgson and Spours 2000a, Hodgson and Spours 2000b; Davies 1999) to comment on full-time 16 -19 year old students' involvement with and attitudes to part-time work in the late 1990s. Although two of the studies include 14-16 year olds, we focus here on 16-19 year olds on advanced level courses because of their greater involvement with the labour market and, more particularly, because it is they who will experience the effects of the Curriculum 2000 qualifications reforms from September 2000 - the major focus of our discussion later in this article. 


\section{The South Gloucestershire Study}

The first of these studies, which will be referred to throughout this article as the South Gloucestershire Study (Hodgson \& Spours 2000a), was carried out between May and July 1999 in six schools and one further education college in the Kingswood area of South Gloucestershire which is located between Bristol and Bath in the south west of England. It involved a closed questionnaire survey of all 14-19 year olds across the seven institutions, 60 semi-structured individual interviews and six group interviews with teachers and careers officers. The questionnaires were administered by the schools and college involved and resulted in 1,997 responses. Examination candidate numbers were used on the questionnaires so that it was possible to select for individual interview a group of 60 students (30 female and 30 male) representing a range of ages and different patterns of part-time employment. Interviews were conducted in the students' school or college and were tape recorded.

\section{The Essex Study}

The second body of research, which we will refer to as the Essex Study (Hodgson and Spours 2000b), consists of 17 institution-based case studies undertaken in 1999 and 2000 by teachers in 17 11-18 schools in different areas of Essex as part of a joint action research project between the Institute of Education and Essex LEA. The teachers involved in the Project designed the data collection instruments themselves, with some support from us, and undertook their own analysis. For this reason, the research projects were not all carried out in the same way and their focus varied to some degree from school to school depending on its particular context and the teacher's primary area of concern. The case-studies use a mixture of quantitative and qualitative 
approaches. In total, across the Essex Study as a whole, just under 2000 sixth formers responded to questionnaires and 112 were interviewed either individually or as part of a group.

\section{The FEDA Study}

The third study we shall be drawing on in this article was undertaken in May 1999 by a researcher from FEDA (Davies 1999). The FEDA Study involved a closed questionnaire survey of a sample of 14-19 year olds in seven secondary schools and seven further education colleges located in Greater London, the South West, East Midlands and South East of England. A total of 555 responses were received and analysed. In addition, each participating institution was also requested to complete and return one copy of a questionnaire designed to elicit staff attitudes towards part-time work. The FEDA Study contains statistical information on student attitudes to work, while the other two studies focus on qualitative evidence on this issue.

\section{The extent of part-time work}

The three studies we draw on here took place during 1999/2000. They all indicate that the incidence of part-time work is significantly higher than that found in previous studies or recorded in a recent Labour Force Survey (DfEE 1999) which recorded that 52 per cent of 16/17 year olds in full-time education were also working part-time.

The recent three studies, however, suggest that between 70 and 80 per cent of 16-19 year olds in full-time education are now involved in paid employment. The South Gloucestershire Study found that 71 per cent of full-time 16-19 year olds worked part-time, though this total included 16 
year olds who might still have been in Year 11. Figures for 17-19 year olds only were higher at 78 per cent. Findings from the Essex Study, which focused only on those in the sixth form, were similar to this latter figure at 81 per cent. The FEDA Study found that 72 per cent of those aged 16 or above and attending school or college were also in paid employment.

These aggregate figures of labour market participation mask differences in the participation of students of different ages. Part-time working increases significantly with age. The South Gloucestershire Study indicated that the number of 18/19 year olds who were in full-time education and also in paid employment was nearly double that of 14 year olds; rising from 42 per cent of 14 year olds to 80 per cent of $18 / 19$ year olds.

This increase is clearly associated with the demarcation between compulsory and postcompulsory education. When young people were asked why older students had more part-time work, they remarked that employers were reluctant to take on young people under the age of 16 for certain jobs. In addition, a peer expectation has developed whereby young people expect to work once they get into the sixth form or college environment in order to demonstrate their financial independence and movement towards adulthood.

Only the FEDA Study examined the relationship between young people's ethnicity and part-time employment and concluded that a higher than average number of white students of British origin and a lower than average number of Asian students of Bangladeshi origin were in paid employment. As we suggest later in the article, this is clearly an area which requires further research.

What all three studies found was that a significant number of those without jobs are actively seeking work. In both the South Gloucestershire and Essex Studies, the majority of non-working 
16-17 year olds were looking for a job. One institutional case study within the Essex Study (Balchin in Hodgson and Spours 2000c) set out to investigate non-working 16-19 year olds. It concluded that the only observable common factor was that these young people lacked the confidence and social skills required to compete in the part-time labour market. Moreover, students themselves felt a set of powerful pressures to work. One Essex advanced level learner felt compelled to remark:

"I do part-time work because if you don't work and don't go out, you will lead a sad life and have poor social skills".

As we shall see later, when we look at the reasons for young people working part-time, there is a complex combination of factors that together help to explain this new cultural norm.

\section{Patterns of work}

All three studies consulted teachers about the issue of part-time work for 16-19 year olds. Teachers' concerns were not so much that students are working (many see this as broadly beneficial) but the number of hours that many of their students are doing and when this work is undertaken. While many teachers thought that too many of their students were working long hours, the three studies found that the majority of 17-19 year olds were working for between six and 15 hours per week and that only a quarter of this age group were working more than 15 hours per week. 
However, what we feel is perhaps more significant is when work is undertaken. The FEDA Study found that 71 per cent of students in paid employment worked during the week and for the Essex Study this figure was nearly 60 per cent. Undertaking paid work on school/college days can disrupt study, but the extent of this disruption depends, we would suggest, on the exact pattern of work. Undertaking paid employment during the week is more disruptive than working at the weekend. This situation was also recognised by students:

"I'd advise Year 11s to work only at weekends when they come into the sixth form" (Essex advanced level learner)

"School work is fresher in your mind in the evening so it's easier to do assignments instead of working at the weekend" (Essex advanced level learner).

We would suggest that the patterns and intensity of employment are related to where students are now working. The three studies, like earlier research (e.g. Dustmann et al. 1996) found that the majority of 16-19 year olds are working in the retail trade. In the South Gloucestershire and Essex Studies, there was some evidence that young people working for supermarkets are subject to contracts that tie them down to a number of hours per week. These contracts may involve up to 18 hours of work per week and the more lucrative Sunday work (paid at time and a half) is often dependent upon undertaking hours of work elsewhere in the week. In addition, there were indications that certain employers put pressure on young people to do additional hours and that it is difficult for young people to say no to this.

"They're more likely to take you on if you're prepared to do a number of hours." (South Gloucestershire advanced level learner) 
The FEDA Study found that nearly half of those with jobs felt they were pressurised by employers to work additional hours against their will.

However, the tendency to work long hours during the week as well as at the weekend cannot be simply explained by employer demands. What is evident from these three studies is that young people can be 'sucked into' longer hours as they become more dependent on the money.

"I didn't need the money before, but now I'd be lost without it." (South Gloucestershire advanced level learner)

Their increased dependency on spending money is compounded by low wage rates which encourage them to work more hours.

"They (the supermarkets) pay low wages. If our age group wants more money, then that would encourage them to do more hours because they get such low wages. " (South Gloucestershire advanced level learner)

To summarise, we would argue that from these recent studies it appears that two factors are interacting to change the volume, pattern and intensity of part-time work among 16-19 year olds. First, changes in retailing practice, in particular the advent of Sunday and 24hour trading, have increased the need for flexible youth labour to undertake unsocial shifts in supermarkets and other shops. Second, peer pressure to undertake significant amounts of work has become overwhelming. In the late 1990s, both opportunity and desire are working together to make part-time work a cultural norm amongst 16-19 year old learners. 


\section{Why young people work}

The three studies, like previous research, found that the major reason for most 16-19 year old learners working is financial. Students gave a variety of financial reasons which ranked as follows: lifestyle pressures (notably socialising, car ownership and the widespread desire for expensive consumer items such as designer clothes, CDs and mobile phones); poverty and need (particularly in relation to one-parent families and independent living); and saving for higher education (a significant minority but a growing phenomenon).

"I need money, I need new clothes, CDs and stuff like that"(South Gloucestershire advanced level learner)

"I don't want to sponge off Mum" (Essex advanced level learner)

"A lot of people I know going to university want to find the money for their fees" (South Gloucestershire advanced level learner)

These financial pressures increase with age and a notable change appears to take place at the beginning of the first year of advanced level study, when many students report that their parents expect them to be more financially independent and responsible.

"Parents say that once you get to a certain age, you sort it out and get a job." (South

Gloucestershire advanced level learner) 
However, as with earlier research (Lucas \& Lammont 1998), the three studies found that there are important non-financial reasons why young people work - notably gaining independence, building self confidence, meeting people and making new friends and developing a CV to help to get a better job in the future

"It's obviously partly to do with the money, but to be honest I think it is a really good experience." (South Gloucestershire advanced level learner)

"Work and study builds up the experience of moving on from compulsory education into a time of choice. I don't have to be doing A levels, I don't have to be doing work, but I choose to do both." (South Gloucestershire advanced level learner)

However, there appear to be limits to what can be learned from this type of work due to the lowlevel nature of the jobs many of the learners in these studies were doing. For some, the drudgery of their job was a powerful motivation to continue studying:

"I would never want to the job I'm doing now for very long" (Essex advanced level learner)

As the students themselves tell us, there are, therefore, several very good reasons for working part-time whilst still at school or college and these reasons are not likely to decrease in importance in the foreseeable future. Indeed, the FEDA Study found that even if 16-19 year olds were offered a grant of $£ 40$ per week while they were studying, more than 50 per cent of them indicated that it would make no difference to the number of hours they would work. 
What the Essex Study shows is that many teachers have now also recognised that a substantial commitment to part-time work has become a fact of life for their advanced level 16-19 year olds:

"It is patently obvious that part-time employment is now the absolute norm for sixth form students in this school. It is as much an ingrained part of their lives as their academic work or their social activities. Those who do not work largely see themselves as deviating from this norm and are frequently embarrassed by the fact." (Essex teacher)

\section{Balancing earning and learning - a perception gap between teachers and learners?}

While teachers broadly appreciate that part-time work can be of benefit to young people, the three studies suggest that there is a perception gap between their views and the views of their students on the impact of part-time paid employment on commitment to study and levels of achievement.

\section{Teachers'views}

Teachers, on the whole, understand why 16-19 year old learners have to undertake part-time paid work. However, they feel that some of their students place too high a priority on their part-time employment and that during the last five years this has altered the cultural climate in sixth forms which has, in turn, compromised commitment to study and to areas of the curriculum such as enrichment and community/voluntary work. The complain that students are often tired in class and are unable to meet homework and meeting coursework commitments. For some students teachers feel that part-time work will damage examination performance. Overall, they feel that 
some students are simply working too many hours in total (e.g. 50+ hours per week of study and paid work). Many teachers appear not to see part-time work as something that a small minority of individuals have got out of balance. Rather they see it as part of a wider more disturbing phenomenon where study does not always come first when earning and learning conflict.

Students' views

Students, by and large, take a rather different view of their ability to balance work and study. All three studies found that students were very sanguine about their ability to do both, even when they were currently underachieving:

"I'll be all right if I pull my socks up next year." (South Gloucestershire advanced level learner)

The FEDA and Essex Studies indicate that there is some student recognition that part-time work might create difficulties in completing homework or meeting course-work deadlines. However, on the whole, students were not prepared to accept that even extensive hours of part-time work might have a negative impact on examination results (Davies 1999). They appear relatively unimpressed when teachers impose thresholds on part-time work based on statistics related to under-performance at A Level and prefer to see the issue as one of individual capacity to cope.

"Some people can mix it, it's down to the individuals" (Essex advanced level learner)

"We know how much time we have. If we worked more, something else would go, but not school work" (Essex advanced level learner) 
However, the South Gloucestershire Study suggests that students are not totally unreflective on this issue, particularly when it involves an assessment of people other than themselves.

"I would probably say that I'm up to date in my assignments and the others that work are a few assignments behind." (South Gloucestershire advanced level learner)

Both teachers and students appear to have a point. From the teacher perspective it appears sensible to accept research based on large data sets (e.g. ALIS 1999 and US research on high school students cited in Rikowski 1992) that indicates that high numbers of hours of part-time work can undermine grade attainment. Moreover, they are right to be concerned by the day-today impact of part-time work on punctuality, meeting coursework deadlines and the amount of time given to independent study. On the other hand, while students tend to be on the optimistic side regarding their capacities to cope, they are correct in assuming that not everyone is the same and some will 'hack it' better than others.

\section{STUDENT TYPOLOGIES AND THE FUNCTIONS OF PART-TIME WORK}

The three studies display both quantitative and qualitative evidence of the positives and negatives of part-time paid work in relation to study. However, the research on the negative impact of increasing amounts of part-time work on examination attainment is not conclusive. Large data sets, such as those provided by ALIS, appear to suggest such a relationship while smaller institution-based studies do not (e.g. the case studies by Newborn, Rawstorne, and Johnson in Hodgson \& Spours 2000b). We would suggest, therefore, that it may be useful to move beyond a 
generalised analysis of the effects of part-time work on study and to develop a more textured view based on the motivation of the student to study and to progress.

\section{Relating full-time study and part-time work: five student types}

In this section we describe five ideal-type categories of students to differentiate the way in which 16-19 year olds relate to study and paid work. These are speculative categories derived from the three studies and other research on Curriculum 2000 (Spours et al. 2000).

\section{The balancers}

The three studies suggest that the 'balancers' are the most numerous group of 16-19 year olds, though they do not necessarily constitute a majority. They are most likely to be undertaking about 10 hours of paid work per week; working a day at the weekend and possibly one weekday evening. Moreover, balancers are usually aiming for higher education and use paid employment both to earn money and to sharpen their ability to get organised, manage time and develop social skills. The Essex Study suggests that girls are better balancers than boys. Two institutional case-studies (Michael and Johnson in Hodgson and Spours 2000b) found that girls were more prepared than boys to do a considerable amount of private study for their A Levels while undertaking paid work.

\section{The risk-takers}

Our research suggests that the next largest group of learners is the 'risk-takers'. There appears to be a little bit of risk-taking in most students, but it is arguably a dominant trait in a significant minority. By risk-taking we mean students taking a personally sanguine view about the effects of 
part-time work on grade achievement; ignoring advice and statistics about the effects of high hours of paid work and preferring to think of themselves as atypical. Risk-takers are more likely to be boys than girls. These are students who may flirt with the idea of higher education and will wait to see how their grades turn out before making a decision about further study. The risk-taker is more likely than the balancer to take on a higher number of hours of work.

\section{The deliberate non-workers}

Deliberate non-workers are those students who, for a variety of reasons, choose not to work parttime. Our research suggests that deliberate non-workers can fall into three separate but sometimes related categories. Some of them are the sons and daughters of affluent parents who are prepared to support their children's lifestyles while they are still at school. A second category is those young people who do not take on a part-time job because they are strongly committed to extra-curricular activities, such as sport, music or drama. Other deliberate non-workers can simply be educationally-focused even when they do not have significant financial support from their parents. This type of student, who constitutes a very small minority of 16-19 year olds participating in full-time education, has decided not to work part-time in order to concentrate on her/his studies in order to achieve the highest possible grades for university entrance.

\section{The outsiders}

A fourth category is what can be termed 'the outsiders'. These too constitute a small minority of 16-19 year olds who may be looking for part-time work but find themselves excluded from the labour market. The South Gloucestershire and Essex Studies found that these students tend to share a number of features - they are often under-confident, lack social skills and do not appear to have the ability to compete in an open labour market. Ironically, they may be exactly the type 
of young person who does require a part-time job in order to widen her/his social horizons and to provide her/him with the skills to participate more fully in society.

\section{The connectors}

The 'connectors' are perhaps the smallest group of 16-19 year olds. These are students who, in addition to financial reasons for working, make active connections between their part-time work and their full-time course. They may, for example, use their workplace as a basis for assignment work. In the South Gloucestershire Study, this type of student could be found in Advanced GNVQ Business courses. Richards and Oates (2000) speculate that making 'connections' between work and study may have a positive effect on examination attainment. Their research in one further education college suggests that part-time work has a differential impact on attainment in different subjects and is particularly important in vocational areas.

In reality, students are likely to display features of each of these ideal types at different times during their advanced level course. However, we would suggest that one type predominates in each case.

These types have been derived from research undertaken during the period prior to changes in the advanced level curriculum. In the next section we consider the role of the curriculum in shaping student behaviour in relation to part-time work.

\section{THE ROLE OF THE CURRICULUM IN EARNING AND LEARNING}

As the role and intensity of part-time work has grown, its relationship to curriculum and achievement has become a central concern for education practitioners. In the previous section we 
suggested that students can construct different types of relationship between study and paid work. In this section we go onto suggest that the advanced level curriculum can also have a differentiated relationship to part-time work - accommodation, tension, balance and connection.

\section{Accommodation - the convenient relationship between 'old' A Levels and part-time work}

The advanced level qualifications system, prior to Curriculum 2000, could be seen as constituting a part-time curriculum which fitted well with growing student engagement in part-time work. 1619 year olds, in both school sixth forms and colleges, came to expect relatively light timetables when studying for A Levels and GNVQs programmes of study, which could comprise as little as 12 hours of teaching per week, easily accommodating substantial commitments to part-time work. There was no nationally required threshold of study hours and students could elect to take as few as two advanced level subjects. Moreover, it was possible, in many cases, for A Level students to take all their examinations at the end of two years of study, leaving the first year free of examination pressure.

Arguably, the marketisation of the education and training system and the resultant institutional competition for 16-19 year olds has produced further pressures for schools and colleges to accept the process of accommodation between advanced level study and part-time work. Schools and colleges have been anxious about losing students by making what could be seen by learners as excessive timetable and study demands. Their apprehensions were compounded by the tendency for 'recruiter' universities to offer places based on low A Level grades. As one sixth form tutor in the South Gloucestershire Study remarked: 
"There is a tacit agreement between local schools and local universities over low grades, so they let kids in with two Es - obviously it depends on the course - but with relatively low grades."

Elsewhere we refer to this 'tacit agreement' between schools, colleges, employers, higher education providers and 16-19 year old learners in the context of a marketised education and training system as a 'low achievement conspiracy' (Hodgson and Spours 1998).

The further education sector, in recent years, has taken this process of accommodation between earning and learning further by timetabling students' programmes in blocks in order to release learners for one or more days during the week. Moreover, some have argued that there is no such thing as a full-time learner and that school and college timetables should be made more flexible to accommodate the new reality (Hughes 1999).

\section{Tension - the effects of an expanded curriculum as a result of the Qualifying for Success reforms}

Tension, in the context of this article, describes a situation where there is conflict created between the demands of the curriculum and the demands of part-time work. 
The new advanced level qualifications reforms, resulting from Qualifying for Success (DfEE 1997), have been explicitly designed to encourage schools and colleges to offer a broader and expanded advanced level curriculum for 16-19 year olds. From September 2000 most students will be expected to take four or more subjects and, in some cases, a key skills qualification as well. Curriculum 2000 (as the reforms are increasingly called) can be seen, therefore, as an attempt by the Government and post-16 providers to reassert more control over an elective curriculum and the process of accommodation between part-time work and study.

The initial expectation is that Curriculum 2000 will create further tension between study and work. Research from the IOE/Nuffield Research Project 'Broadening the Advanced Level Curriculum: Institutional Responses to the Qualifying for Success Reforms' suggests that these reforms are largely popular with students due to start post-16 study in September 2000 (Spours et al. 2000). In many cases they are aware that they may have to limit the number of hours of parttime work they can undertake with the new curriculum. However, the Essex Study suggests that not all students will be willing to limit their hours of work in response to increased study demands.

An additional factor in relation to Curriculum 2000, is that there are potentially more 'pressure points' for students as a result of the modular nature of the new advanced level qualifications. Students will have to strive harder to balance study and work because they will be assessed throughout their course and not just at the end.

However, the voluntarist nature of the Curriculum 2000 reforms, together with the continued effects of a marketised post-16 education and training system, may give students the power to push institutions into an accommodation mode in relation to the new curriculum. Schools and colleges who tend to attract 'weaker' students and who need to recruit may be prepared to 
recommend that substantial numbers of students take fewer than four subjects in their first year; thus effectively ensuring that they have lighter timetables than initially anticipated with the new advanced level curriculum.

Overall it is possible, therefore, that the tension arising from Curriculum 2000 will evoke different types of behaviour in different types of student - more balancing with the emphasis on improved time-management on the one hand and more risk-taking on the other.

\section{Balance - compartmentalising the relatively separate worlds of study and work}

Balance suggests a state of 'co-existence' between full-time study and the increased reality of part-time work. In this situation, students confine their part-time work to a relatively low number of hours (e.g. fewer than 10 per week) or to seasonal or holiday work and recognise that employment provides them with experiences that school might not (e.g. developing the social skills required to work face-to-face with adults). The concept of balance suggests the reduction of many of the negative effects of part-time work on study while retaining the significant personal benefits of part-time employment. Balance can even be achieved when young people see study and part-time work as quite separate. A state of balance is possible with Curriculum 2000, but it would mean that young people would have to work fewer hours than many current 16-19 year olds devote to paid employment. 


\section{Connection - relating advanced level study and part-time work}

Connection is an active form of balance that relies on a closer relationship being forged between the curriculum and part-time work. The studies we have cited in this article suggest vocational courses such as GNVQs sometimes provide the context for connection because students can use their experience of paid work as a basis for their assignments. It is possible that the Curriculum 2000 reforms could increase the 'moments of connection' for a wider range of students through requirements to achieve key skills, although this is more likely to happen in relation to the wider key skills than the three key skills currently required for the Key Skills Qualification.

At present, however, there is very little evidence of this type of connection taking place and our research in South Gloucestershire suggests that students are currently more inclined to want to balance the separate worlds of study and work than to connect them. Connection is unlikely to be student-led or institutionally-led. It will require, we would argue, a national steer, considerable curriculum and staff development in schools and colleges and a change of attitude by most employers towards their part-time employees.

\section{THE NEED FOR RESEARCH ON THE ROLE OF PART-TIME WORK IN THE NEW CURRICULUM AND POLICY CONTEXT}

All the research into earning and learning in the late 1990s suggests that part-time work constitutes a major part of young people's lives and that this situation is not likely to change. 
The implications of this pervasive phenomenon need, therefore, to be actively considered in relation to a range of educational and social reforms for 16-19 year olds. In this respect, Curriculum 2000 is particularly significant. The encouragement to take more subjects and key skills is on a potential collision-course with growing student commitment to part-time work. Schools and colleges hope that advice and guidance can influence more students to become 'balancers'. However, current trend points to a greater number of 'risk-takers' and a position of 'curriculum tension'. If this is the case, the consequences could be that levels of achievement will suffer and, more immediately, that additional subjects will be dropped with the potential to undermine the broadening objective of Curriculum 2000.

In addition, growing student commitment to part-time work could affect a range of other reforms, including the introduction of Educational Maintenance Allowances; targets for participation in higher education, with financial support for the poorest participants; and an increase in the quantity and improvement of the quality of Modern Apprenticeships. There is urgent need to research the impact of the changes in labour market participation on a whole range of current policy initiatives aimed at young people.

But first there is a need for a clearer national picture of the phenomenon of part-time work amongst full-time 16-19 year olds. In the late 1990s, research has relied largely on local studies which have tended to be located in the South of England. A much broader study is required to examine the incidence of part-time work among 16-19 year olds in different regional labour markets and among different socio-economic and ethnic groups. It would also be important for any research of this type to take a longitudinal approach to this issue in order to explore the longer-term implications of part-time work for transitions from school and college to further study, adult and working life. Moreover, such research should involve employers. 
Earning and learning is the new common experience for 16-19 year olds. The way young people get involved with post-16 education and work is changing with significant implications for policies aimed at expanding educational participation and raising levels of achievement. The role of part-time work for full-time learners has become an issue that policy-makers can no longer afford to ignore. 


\section{REFERENCES}

A LEVEL INFORMATION SERVICE (ALIS) (1999) Part-time work: ALIS data set (CEM Centre, University of Durham)

BALL, S. MAGuiRe, M. \& MACRAE, S. (2000) Choice, Pathways and Transitions Post-16 (London, Routledge/Falmer)

BYNNER, J., FERRI, E. \& SMITH, K. (1997) Getting Somewhere, Getting Nowhere in the 1990s, in BYNNER, J., FERRI, E., SHEPHARD, D., JOSHI, H. PIERELLA, P., SMITH, K., MONTGOMERY, S., AND WIGGINS, R. (Eds) Twenty-somethings in the 1990s: Getting on, getting by and getting nowhere in the 1990s (Aldershot, Ashgate)

COLES, M. (1998) An investigation into the part-time employment undertaken by 16-19 year old students alongside their full-time studies MA dissertation (University of Sheffield)

DAVIES, C. (1998) DTI consultation on measures to implement provisions for EU directives on the organisation of working time and the protection of young people at work Letter to the Secretary of State for Trade and Industry, (Wallington High School for Girls, Surrey)

DAVIES, P. (1999) Learning and Earning: The Impact of Paid Employment on Young People in Full-Time Education (London, FEDA)

DEX, S. \& MCCULLOCH, A. (1995) Flexible Employment in Britain: a statistical analysis (Manchester, Equal Opportunities Commission) 
DEPARTMENT FOR EDUCATION AND EMPLOYMENT (DfEE) (1997) Qualifying for Success: A consultation paper on the future of post-16 qualifications (London, DfEE)

DfEE (1999) Education and Labour Market Status of Young People Aged 16-18 in England: 1992-1998 Statistical Bulletin 11/99 (London, DfEE)

DUSTMANN, C., MICKLEWRIGHT, J. RAJAH, N. \& SMITH, S. (1996) Earning and learning: education policy and the growth of part-time work by full-time pupils, Fiscal Studies 17, No 1, pp 79-105

FORD, J., BOSWORTH, D. AND WILSON, R. (1995) Part-time work and full-time higher education, Studies in Higher Education 20, No 2, pp 187-202

HAKIM, C. (1996) Working Students. Students in full-time education with full-time and part-time jobs Working Paper 8 (Department of Sociology, London School of Economics)

HANNAN, D., RAFFE, D. \& SMYTH, E. (1996) Cross-National Research on School to Work Transitions: An Analytic Framework Report to the OECD (Paris, OECD)

HARRIS, B. (1999) Part-time jobs eats into A-level revision time, The Independent 20 May

HARRISON, D. (1998) Superstores use school timetables to get hold of pupils who are free to stack shelves, The Observer 19 July

HOBBS, S. \& MCKECHNIE, J. (1997) Child Employment in Britain (The Stationary Office, Edinburgh) 
HODGSON, A. \& SPOURS, K. (1998) Pushed too far?, Times Education Supplement 11 December

HODGSON, A. \& SPOURS, K. (2000a) Earning and Learning A local study of part-time paid work among 14-19 year olds Report No 1, (Lifelong Learning Group, Institute of Education, University of London)

HODGSON, A. \& SPOURS, K. (2000b) Finding a balance: the relationship between parttime work and full-time study in Essex secondary schools Report No 2, (Lifelong Learning Group, Institute of Education, University of London)

HODGSON, A. \& SPOURS, K. (2000c) Earning to learn?, The Guardian Education 4 July

HODKINSON, P., SPARKES, A. \& HODKINSON, H. (1996) Triumphs and Tears: young people, markets and the transition from school to work (London, David Fulton)

HOWARD, I. (1998) Does part-time employment affect A Level grades achieved? (Halesowen College, West Midlands)

HUGHES, C. (1999) Teenagers Learning and Earning FEDA Press Release, 15 July 1999 (London, FEDA)

LUCAS, R. \& LAMMONT, N. (1998) Combining work and study: an empirical study of fulltime students in school, college and university, Journal of Education and Work, 11, pp 41-56 
MICKLEWRIGHT, J., RAJAH, N. \& SMITH, S. (1994) Labouring and learning: part-time work and full-time education, National Institute Economic Review, May, pp 73-85

O’DONNELL, C. \& WHITE, L. (1998) Invisible Hands: Child Employment in North Tyneside (London, Low Pay Unit)

POND, C. \& SEARLE, A. (1991) The Hidden Army: Children at work in the 1990s (London, Low Pay Unit)

RAFFE, D., BIGGART, A., FAIRGREIVE, J. \& HOWIESON, C. (1998) OECD Thematic

Review - The Transition from Initial Education to Working Life: UK Background Report (Centre for Educational Sociology, University of Edinburgh)

RICHARDS, L. \& OATES, T. (2000) Not as young as they were: the impact of combining working and learning amongst 16-19 year olds in full-time education Discussion Paper, (University of Brighton)

RIKOWSKI, G. (1992) Working for Leisure? Part-time and Temporary Working Amongst A Level and BTEC Students at Epping Forest College (Division of Humanities and Modern Languages, Epping Forest College)

RUBERY, J., SMITH, M., FAGAN, C. \& GRIMSHAW, D. (1998) Women and the European Employment Rate (London, Routledge)

SPOURS, K., SAVORY, C. \& HODGSON, A. (2000) Current Advanced Level Provision in England and Early Institutional Responses to ‘Curriculum 2000’ IOE/Nuffield Project Research Report 2, (Lifelong Learning Group, Institute of Education, University of London) 
